\title{
Exogenous and endogenous contribution to nitrogen fluxes in the digestive tract of pigs fed a casein diet. I. Contributions of nitrogen from the exocrine pancreatic secretion and the bile
}

\author{
T Corring 1*, WB Souffrant 2 , B Darcy-Vrillon 1 , \\ G Gebhartd 2, JP Laplace 1, A Rérat 1
}

with the technical assistance of F Cointepas ${ }^{1}$ and G Brachet 1

1 Station de Physiologie de la Nutrition, INRA-CRJ, 78352 Jouy-en-Josas Cedex, France

2 Karl-Marx-Universität Leipzig, Sektion Tierproduktion und Veterinärmedizin, Wissenschaftsbereich

Tierernährungsphysiologie und Futtermittelkunde, 7022 Leipzig, G Kuhn Str, 08 Germany

(Received 20 February 1990; accepted 2 October 1990)

Summary - The aim of the present work was to study the endogenous contribution of the exocrine pancreatic and biliary secretions to the total endogenous nitrogen production in the pig. Three growing Large White pigs weighing $45 \pm 2.5 \mathrm{~kg}$ were fitted with permanent fistulae in the pancreatic duct, the bile duct and the duodenum. They were adapted to a semi-synthetic casein diet for $14 \mathrm{~d}$ before surgery. In a 7-d post-operative period and an 8-d experimental period, they were fed the same diet. Secretion rates were recorded, total nitrogen and TCA (trichloroacetic acid) insoluble nitrogen were determined in representative pancreatic juice and bile samples.

Daily pancreatic juice and bile flow rates were very similar: 1850 and $1820 \mathrm{ml}$, respectively. The amount of endogenous total nitrogen secreted in the intestinal lumen was $3.6 \mathrm{~g}$ per day: $1.9 \mathrm{~g} \mathrm{~N}$ through pancreatic secretion and $1.7 \mathrm{~g} \mathrm{~N}$ through bile secretion. Pancreatic nitrogen increased after meal intake, whilst the kinetics of nitrogen production in the bile were not affected. Throughout the experiment, the mean percentage of TCA insoluble nitrogen was $78.1 \%$ in pancreatic juice and $72.3 \%$ in bile.

endogenous nitrogen / pancreatic juice / bile / pig

Résumé - Contributions exogènes et endogènes aux flux d'azote dans le tube digestif des porcs nourris d'un régime à base de casélne. I. Contrlbution de la sécrétion pancréatlque exocrine et de la bile. La contribution des sécrétions pancréatique et biliaire à la production d'azote endogène a été étudiée chez le porc. Trois porcs Large White d'un poids moyen de $45 \pm 2,5 \mathrm{~kg}$ ont été munis de fistules permanentes dans le canal pancréatique, le canal biliaire et le duodénum. Ils ont été adaptés à un régime semi-synthétique à base de caséine pendant 14 j avant lintervention chirurgicale et ont reçu ce même régime au cours d'une période de récupération post-opératoire de $7 j$ et d'une période expérimentale de 8 j. L'azote total, l'azote insoluble dans l'acide trichloracétique (ATC) et les volumes sécrétés ont été déterminés pendant la période expérimentale.

Les volumes quotidiens de suc pancréatique et de bile ont été respectivement de 1850 et 1820 $\mathrm{ml}$. La quantité d'azote total sécrétée dans la lumière intestinale a été de $3,6 \mathrm{~g} / \mathrm{j}: 1,9 \mathrm{~g}$ provenant de la sécrétion pancréatique et $1,7 \mathrm{~g}$ de la sécrétion biliaire. La quantité d'azote pancréatique augmente après la consommation du repas, tandis que celle produite par la sécrétion biliaire n'a pas été affectée. Au cours de la période expérimentale, le pourcentage moyen d'azote insoluble dans ATC a été de $78,1 \%$ dans le suc pancréatique et de $72,3 \%$ dans la bile.

azote endogène / suc pancréatique / bile / porc

\footnotetext{
* Correspondence and reprints
} 


\section{INTRODUCTION}

During transit in the digestive tract, dietary proteins are submitted to various processes: hydrolysis by the enzymes of endogenous secretions and subsequent amino acid absorption, as well as degradation and utilisation by the intestinal microorganisms. The purpose of a series of studies was to study all these processes simultaneously in order to determine exogenous and endogenous contribution to nitrogen fluxes in pigs fed the same casein diet. Transit and digestion at the end of the small intestine were assessed by ileal digesta collection, according to Darcy et al (1980). The contribution of the large intestine was assessed by measurements performed in fæces. The contribution of pancreatic and biliary secretions to nitrogen fluxes in the digestive tract was measured according to Corring et al (1972) and Juste et al (1979). The appearance of nitrogen and amino acids in the efferent blood was studied by simultaneous measurement of porto-arterial concentration differences and portal blood flow rate (Rérat et al, 1980). In addition, using an isotopic labeling technique $\left({ }^{15} \mathrm{~N}\right)$, we were able to dissociate the study of exogenous vs endogenous nitrogen digestion and absorption.

In this first paper we report data on the contribution of nitrogen from the exocrine pancreatic secretion and the bile. The experiment was carried out on the same animals fed a semi-synthetic casein diet.

\section{MATERIALS AND METHODS}

\section{Animals and diet}

Three Large White female pigs were fitted with permanent fistulæ in the pancreatic duct, the bile duct and the duodenum (Corring et al, 1972; Juste et al, 1979) at a mean live weight of $45 \pm$ $2.5 \mathrm{~kg}$. Because these pigs were also used in a study in which endogenous nitrogen was labelled with ${ }^{15} \mathrm{~N}$ L-leucine, they were fitted with a catheter in the carotid artery and jugular vein, and with a urinary probe. Results on labelling of endogenous nitrogen will be given in a separate paper. After surgery, the animals were housed in metabolism-type cages. They were adapted to a casein diet (15\% total proteins) for $14 \mathrm{~d}$ before surgery. The diet, the composition of which is reported in table 1 , was given during a $7-d$ recovery period and an 8-d experimental period. The diet was provided in 2 daily meals of $800 \mathrm{~g}$ each diluted in water $(1 / 1)$ at 9.00 and $16.00 \mathrm{~h}$.

\section{Pancreatic juice and bile samplings and analysis}

At the end of surgery, pancreatic juice and bile were returned to the animals by 2 automatic de-

Table I. Composition of the diet.

$\begin{array}{llc} & \text { Purified wheat starch } & 72.3 \\ & \text { Hydrochloric casein } & 16.1 \\ \text { Ingredients (\%) } & \text { Cellulose } & 6.0 \\ & \text { Peanut oil } & 2.0 \\ & \text { Minerals and vitamins } & 3.6 \\ \text { Chemical } & \text { Total nitrogen } & 2.37 \pm 0.10 \\ \text { composition (*) (\%) } & & \end{array}$

\footnotetext{
- Mean \pm SEM of 3 determinations performed in the 2 laboratories.
} 
vices which restituted the digestive secretion immediately at a rhythm mimicking normal secretion (Juste et al, 1983a). Using these devices, it was possible to measure the volume drained and to take representative and continuous samples of $\approx 4 \%$ of the juice collected. During the 8 d experimental period, pancreatic juice and bile were sampled every day and samples were pooled in 2-h fractions. Such an experimental pattern allowed a study to be made of the response of both digestive secretions to the 9.00 meal. Because the 16.00 meal was located during a collecting period (from 15.00 to $17.00 \mathrm{~h}$ ) the present study would not permit any conclusion to be reached about the response of pancreatic and bile secretions to this second daily meal.

Total nitrogen (Kjeldahl method) was determined in each pancreatic juice and bile pooled sample according to the following procedure: 5 ml 10\% TCA (trichloracetic acid) solution were added to $5 \mathrm{ml}$ of pancreatic juice or bile. After centrifugation ( $5000 \mathrm{~g}, 15 \mathrm{~min}$ ) the precipitate was mixed with $2 \mathrm{ml} \mathrm{10 \%} \mathrm{TCA} \mathrm{instead} \mathrm{of} 5 \%$ TCA in order to complete the extraction procedure, and centrifuged. Supernatants were pooled and the sediment isolated. Total nitrogen was determined in each fraction. All data were processed by Student's $t$-test, and results are given as means \pm SEM.

\section{RESULTS AND DISCUSSION}

\section{Pancreatic juice and bile flow rates}

The mean volume of pancreatic juice secreted (fig 1) changed within $24 \mathrm{~h}$. It increased significantly between the 2 nd and the 4th $\mathrm{h}$ after the 9.00 meal $(P<0.05$, relative to the $2 \mathrm{~h}$ period before feeding) and within the 6-8 period following it. Maxima values were $\approx 180 \mathrm{ml} / 2 \mathrm{~h}$, whereas lowest values were obtained at the end of the nocturnal period and were $\approx 120 \mathrm{ml} / 2 \mathrm{~h}$. The total volume of pancreactic juice seceted within $24 \mathrm{~h}$ was $1850 \pm 88 \mathrm{ml}$.

Bile flow rate (fig 2) was more stable over the $24 \mathrm{~h}$ period, mean values being $\approx 150 \mathrm{ml} / 2 \mathrm{~h}$. The total volume of bile secreted per day was $1820 \pm 48 \mathrm{ml}$.

As far as the pancreatic secretion was concerned, the daily volume of juice secreted was in the range of values obtained by others (Partridge et al, 1982; Zebrowska et al, 1983; Corring et al, 1986; Langlois et al, 1987). The pancreatic juice flow rate was shown to be affected by the concentration of the diet (ie, liquid, solid, semisynthetic or natural), being lower with a semi-synthetic diet (Partridge et al, 1982; Zebrowska et al, 1983).

The daily bile volume was similar to that obtained in pigs fed a semi-synthetic diet with a low lipid content (Juste, 1982). How-

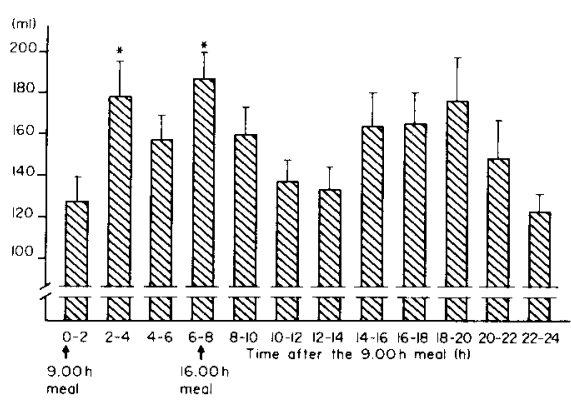

Fig 1. Exocrine pancreatic secretion flow rates (ml/2 h). Means \pm SEM. 3 animals, $n=24, \bar{x}=$ $1850 \mathrm{ml} / \mathrm{d}$. $* P<0.05$, relative to the $2-\mathrm{h}$ period before the $9.00 \mathrm{~h}$ meal.

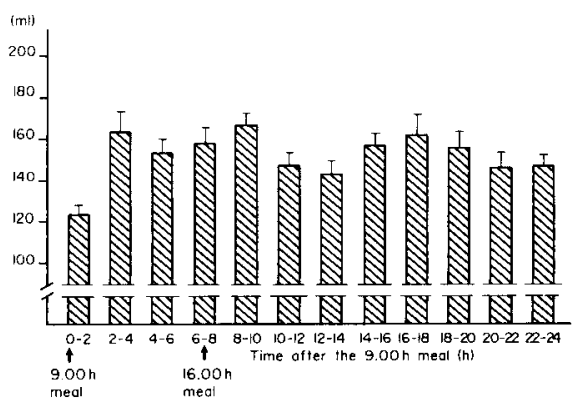

Fig 2. Bile secretion flow rates $(\mathrm{ml} / 2 \mathrm{~h})$. Means \pm SEM. 3 animals, $n=24, \bar{x}=1820 \mathrm{ml} / \mathrm{d}$. 
ever, it was shown that bile flow rate increased with a lipid-enriched diet (Aliev and Khamzatov, 1980; Juste et al, 1983b).

\section{Nitrogen concentration and production}

Total nitrogen concentration in the pancreatic juice did not significantly change over the $24 \mathrm{~h}$, and varied from 0.77 to 1.22 $\mathrm{mg} / \mathrm{ml}$ (fig 3). During the experimental period, the mean value was $1.01 \pm 0.11 \mathrm{mg} /$ $\mathrm{mi}$.

The total nitrogen concentration in bile was more constant, varying from 0.88 to $1.10 \mathrm{mg} / \mathrm{ml}$ (fig 4). The mean value over

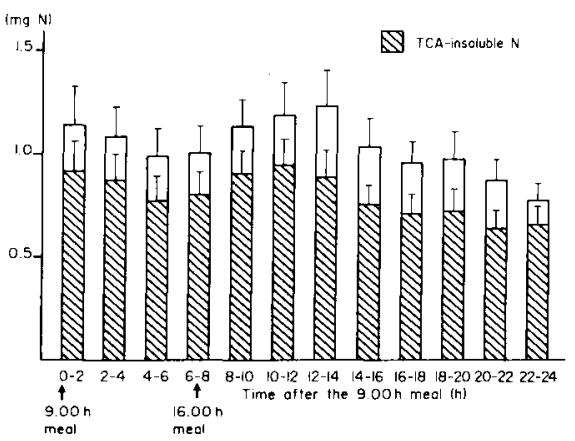

Fig 3. Total $N$ and TCA insoluble $N$ concentrations in pancreatic juice (mg $\mathrm{N} / \mathrm{ml})$. Means \pm SEM. 3 animals, $n=24$.

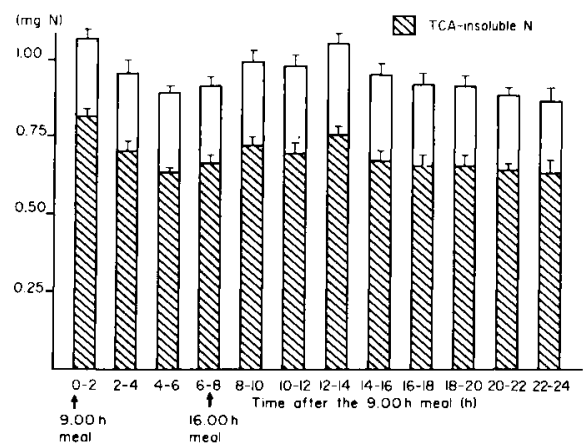

Fig 4. Total $\mathrm{N}$ and TCA insoluble $\mathrm{N}$ concentrations in bile (mg $\mathrm{N} / \mathrm{ml}$ ). Means \pm SEM. 3 animals, $n=24$. the experimental period was $0.96 \pm 0.02$ $\mathrm{mg} / \mathrm{ml}$.

Figure 5 shows that total nitrogen production in the pancreatic secretion was highest after intake of the 2 daily meals and reached $195 \mathrm{mg} / 2 \mathrm{~h}$ following the 9.00 meal. The basal production observed at the end of the nocturnal period was $95 \mathrm{mg} /$ $2 \mathrm{~h}$. The daily production of total nitrogen secreted by the exocrine pancreas was $1905 \pm 218 \mathrm{mg}$.

The total nitrogen production in bile (fig 6) changed only a little within $24 \mathrm{~h}$ (130 to $165 \mathrm{mg} / 2 \mathrm{~h}$ ). The daily production was $1721 \pm 70 \mathrm{mg} \mathrm{N}$.

The amount of endogenous total nitrogen secreted through pancreatic and bile secretions into the intestinal lumen of a 45 $\mathrm{kg}$ live weight pig was $3.6 \mathrm{~g}$ per day, ie $22.6 \mathrm{~g}$ of total proteins ( $\mathrm{N} \times 6.25$ ). This is the first time that such a result was obtained in the same animal.

The exocrine pancreatic secretion produced $1.9 \mathrm{~g} \mathrm{~N}$ per day, a value similar to those obtained by Zebrowska et al (1983) in pigs fed a semi-synthetic diet. The pancreatic nitrogen production was shown to depend on the nature of the dietary protein, but also on the concentration of the

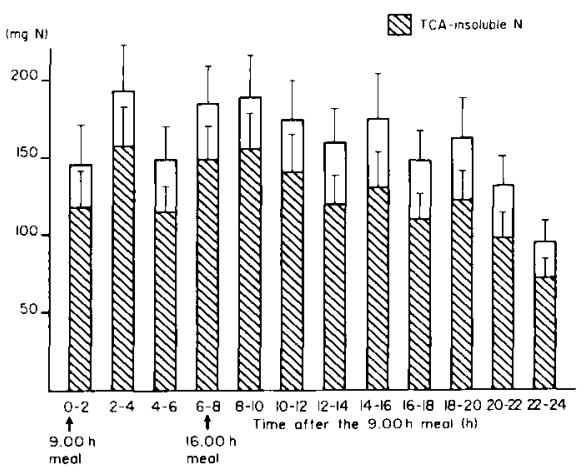

Fig 5. Total $N$ and TCA insoluble $N$ production in pancreatic juice (mg N/2 h). Means \pm SEM. 3 animals, $n=24 ; \vec{x}=1.905 \mathrm{mg}$ total $\mathrm{N} / \mathrm{d} ; \overrightarrow{\mathrm{x}}=$ $1486 \mathrm{mg}$ TCA insoluble N/d. 


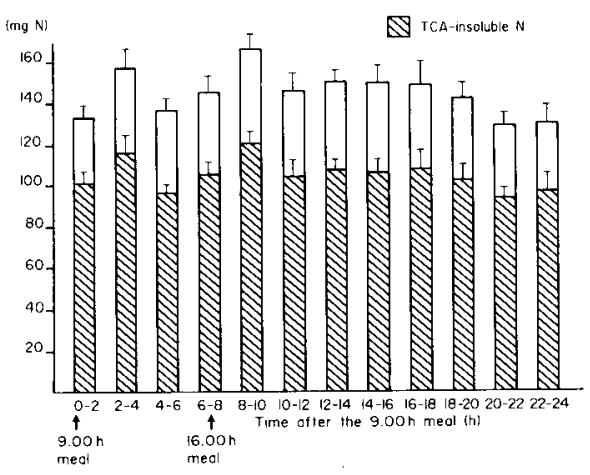

Flg 6. Total $\mathbf{N}$ and TCA insoluble $\mathbf{N}$ production in bile (mg N/2 h). Means \pm SEM. 3 animals, $n=$ $24 ; x=1721 \mathrm{mg}$ total $N / d ; \bar{x}=1244 \mathrm{mg}$ TCA insoluble $\mathrm{N} / \mathrm{d}$.

diet. It was lower in animals fed a semisynthetic diet than in animals given a normal diet with similar amounts of nutrients (1.9 g vs $2.1 \mathrm{~g}$ according to Zebrowska et al, $1983 ; 1.1 \mathrm{~g}$ vs $1.5 \mathrm{~g}$ according to Partridge et al, 1982). The pancreatic endogenous total nitrogen production was $2.1 \mathrm{~g}$ per day in the pig fed heated soyabean (Corring et al, 1986) or $2.3 \mathrm{~g}$ per day when the diet contained wheat (Langlois et al, 1987). Furthermore, the present study shows that the amount of pancreatic nitrogen increased after meal intake, as reported earlier (Corring, 1980).

The daily bile secretion into the intestinal lumen included $1.7 \mathrm{~g}$ of endogenous nitrogen, which was close to the values reported by Sambrook (1981); the concentration of the diet did not appear to affect the daily production of endogenous nitrogen through bile secretion (Sambrook, 1981). In contrast to pancreatic secretion, meal intake did not affect the kinetics of nitrogen production in bile.

From results obtained by different authors, Low (1980) determined that the total endogenous nitrogen production in the di- gestive tract of a 40-50 kg live weight pig was $\approx 18 \mathrm{~g}$ per day. Taking into account this value, data in the present work showed that the exocrine pancreatic and biliary contribution to total endogenous nitrogen production was $20 \%$. Moreover, exocrine pancreatic and bile nitrogen production represented $\approx 15 \%$ of ingested protein. The bile contribution $(\approx 7 \%)$ was in the range of values reported by Juste (1982). The pancreatic contribution $(\approx 8 \%)$ also corresponded to values reported by Juste (1982), but was lower than that determined by Corring (1975) in pigs fed a cerealbased diet.

The TCA insoluble form of nitrogen remained quite constant over $24 \mathrm{~h}$ and represented $75-82 \%$ in the pancreatic juice and $70-76 \%$ in bile. Throughout the experiment the mean percentage of TCA insoluble nitrogen was 78.1 in the pancreatic juice, higher than the value reported by Corring and Jung (1972), and 72.3 in bile. In the pig pancreatic juice we found (unpublished data) that digestive enzymes represented $\approx 90 \%$ of the TCA insoluble form of nitrogen. In man, the non-protein nitrogen mainly comes from amino-sugars and amides, especially urea, and also from mucoproteins which are TCA-soluble (Altman, 1961). Concerning bile secretion, data on the composition of TCA insoluble nitrogen are not available; but Altman (1961) reported that in man, it represented $71-78 \%$ of total nitrogen.

In conclusion, the present study shows that in the same pig fed a casein diet, daily pancreatic juice and bile flow rates were very similar, whilst the amount of endogenous total nitrogen secreted into the intestinal lumen was $3.6 \mathrm{~g}$ per day: $1.9 \mathrm{~g}$ through pancreatic secretion and $1.7 \mathrm{~g}$ through bile secretion. The mean percentage of TCA insoluble nitrogen was 78.1 in the pancreatic juice and 72.3 in bile. 


\section{REFERENCES}

Aliev AA, Khamzatov ZZ (1980) Bile secretion in young pigs in relation to lipid nutrition. Dokj Vses Ordena Lenina Akad Skh Nauk Im VI Lenina 2, 29-31 (in Russian)

Altman PL (1961) In: Biological Handbooks: Blood and Other Body Fluids (Dittmer DS, ed) Fed Am Soc Exp Biol, 409-415

Corring T (1975) Apport de protéines d'origine endogène par la sécrétion du pancréas exocrine chez le porc. Ann Biol Anim Biochim Biophys 15, 115-118

Corring $T$ (1980) Endogenous secretions in the pig. In: Current Concepts of Digestion and Absorption in Pigs. (Low AG, Partridge IG, eds). NIRD, HRI, Ayr, Tech Bull 3, 136-150

Corring T, Aumaitre A, Rerat A (1972) Fistulation permanente du pancréas exocrine chez le porc. Application : réponse de la sécrétion pancréatique au repas. Ann Biol Anim Biochim Biophys 12, 109-124

Corring T, Jung J (1972) The amino acid composition of pig pancreatic juice. Nutr Rep Int $6,187-190$

Corring T, Gueugneau AM, Chayvialle JA (1986) Short-term (8-days) effects of a raw soybean diet on exocrine pancreatic secretion and plasma gastrointestinal hormone levels in the pigs. Reprod Nutr Dév 26, 503514

Darcy B, Laplace JP, Villiers PA (1980) Digestion dans l'intestin grêle chez le porc. II. Cinétique comparée de passage des digesta selon le mode de fistulation, iléo-caecale ou iléo-colique post-valvulaire, dans diverses conditions d'alimentation. Ann Zootech 29, 147-177
Juste C (1982) Apports endogènes par les sécrétions digestives chez le porc, 155-173. In: Physiologie Digestive chez le Porc (Laplace $J P$, Corring T, Rérat A, eds) $2^{\theta}$ Sém Int Jouyen-Josas-Versailles (France), Colloques de I'INRA, No 12

Juste C, Corring T, Breant $P$ (1979) Excrétion biliaire chez le porc : niveau et réponse au repas. Ann Biol Anim Biochim Biophys 19, 7990

Juste C, Corring T, Le Coz Y (1983a) Bile restitution procedure for studying bile secretion in fistulated pigs. Lab Anim Sci 33, 199-202

Juste C, Demarne Y, Corring T (1983b) Response of bile flow, biliary lipids and bile acid pool in the pig to quantitative variations in dietary fat. J Nutr 113, 1691-1701

Langlois A, Corring T, Fevrier C (1987) Effects of wheat bran on exocrine pancreas secretion in the pig. Reprod Nutr Dév 27, 929-939

Low AG (1980) Nutrient absorption in pigs. J Sci Food Agric 31, 1087-1130

Partridge IG, Low AG, Sambrook IE, Corring T (1982) The influence of diet on the exocrine pancreatic secretion of growing pigs. $\mathrm{Br} J$ Nutr 48, 137-145

Rérat A, Vaugelade P, Villiers PA (1980) A new method for measuring the absorption of nutrients in the pig: critical examination. In: Current Concepts of Digestion and Absorption in Pigs (Low AG, Partridge IG, eds) NIRD, HRI, Ayr, Tech Bull 3, 177-214

Sambrook IE (1981) Studies on the flow and composition of bile in growing pigs. $J \mathrm{Sci}$ Food Agric 32, 781-791

Zebrowska T, Low AG, Zebrowska H (1983) Studies on gastric digestion of protein and carbohydrate, gastric secretion and exocrine pancreatic secretion in the growing pig. $\mathrm{Br} J$ Nutr 49, 401-410 